\title{
Kernos
}

Revue internationale et pluridisciplinaire de religion grecque antique

$24 \mid 2011$

Varia

\section{Pan's Tree: On a Votive Relief to Pan from the Piraeus}

Robert S. Wagman

\section{(2) OpenEdition \\ Journals}

\section{Electronic version}

URL: http://journals.openedition.org/kernos/1940

DOI: 10.4000/kernos. 1940

ISSN: 2034-7871

\section{Publisher}

Centre international d'étude de la religion grecque antique

\section{Printed version}

Date of publication: 1 January 2011

Number of pages: 105-109

ISSN: 0776-3824

Electronic reference

Robert S. Wagman, «Pan's Tree: On a Votive Relief to Pan from the Piraeus », Kernos [Online], 24 | 2011, Online since 01 February 2014, connection on 30 April 2019. URL : http:// journals.openedition.org/kernos/1940 ; DOI : 10.4000/kernos.1940 
Kernos 24 (2011), p. 105-109.

\section{Pan's Tree:}

\section{On a Votive Relief to Pan from the Piraeus}

Abstract: The article offers a brief discussion of tree and cave representations in Greek art, tracing a tendency of these two landscape motifs to overlap or appear in conflated form.

Résumé : Cet article propose une brève discussion de la représentation des arbres et des grottes dans l'art grec, en soulignant la tendance de ces deux motifs paysagers à se recouvrir ou à se confondre sur un plan formel.

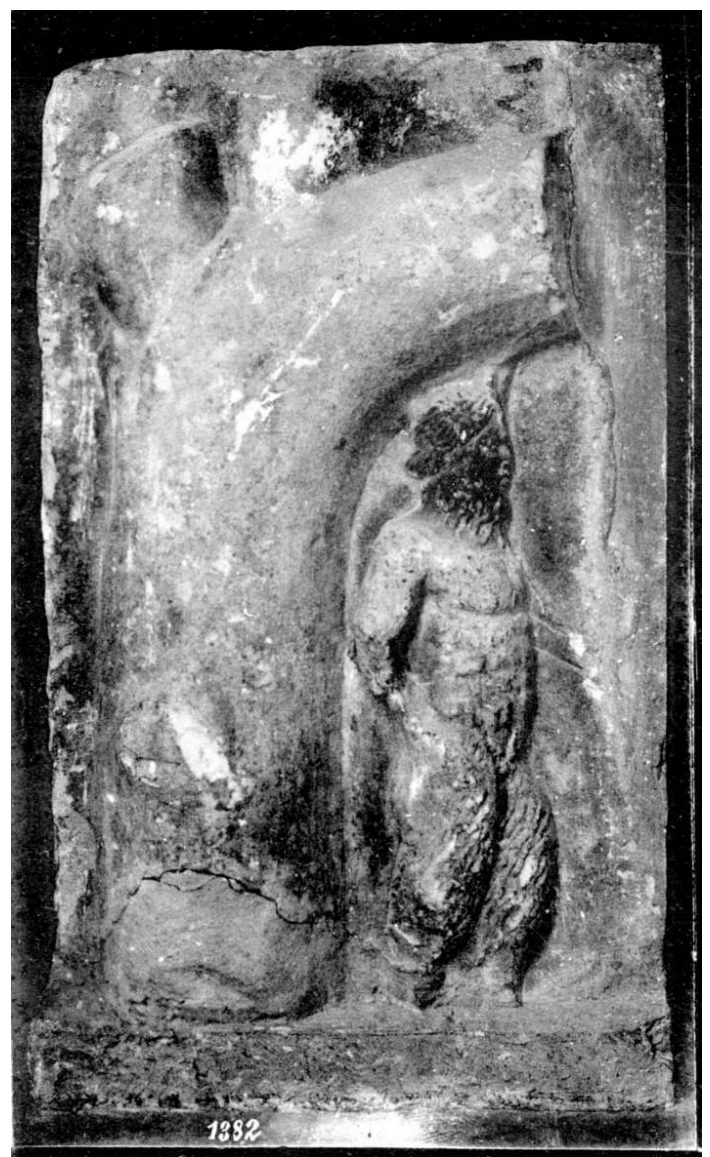

Athens, NM 1382. Votive relief of white marble, broken to the right. Height: 0.48. Max. Width: 0.29. Found in Piraeus in 1842; now at the National Archaeological Museum, cat. 1382. Pan, bearded and goatfooted, is shown standing under a massive tree carved against the left edge of the relief. In his left hand, now damaged, he holds what appears to be a lagobolon. Fourth century BC [see I.N. SvORONOS, Tò Év

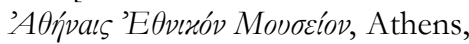
1903 , n. 79 , p. $327-328$, pl. XLIX (with earlier bibliography)]. 
The one odd feature in this otherwise unremarkable relief is the tree, "a bare, stocky tree with severely cut-back branches."1 Rising stiffly behind Pan, the massive trunk of this plant curves over the god's head framing his figure under a semi-arch. Carved in right profile, the Goat God fits snugly in the vertical space thus created like a statue in a niche. ${ }^{2}$ There is an unusual lack of natural movement in the resulting composition, as the tree has a lifeless quality which would be more appropriate to an inanimate object than a live plant.

What appears to be at work here is the conflation of two different landscape motifs. Even more so than trees, caves belong to the traditional iconography of Pan and the Nymphs. ${ }^{3}$ Overlapping with the shape of the tree, in our relief, is the shape of a profiled cave, of the semi-arched type often seen in vase painting scenes of the Archaic and Early Classical periods. ${ }^{4}$ In relief sculpture, this cave type makes occasional appearances well into Roman and Imperial times; an illustrative example is that of the cave of Cerberus in a votive relief from Naples of the second century C.E. ${ }^{5}$

The associative process which lead to the fusion of these two pictorial elements is not difficult to reconstruct. Trees and caves are intimately related features of the Greek religious landscape, often found in close spacial proximity.

${ }^{1}$ M.P. CARROLL-SpILLECKE, Landscape Deptictions in Greek Relief Sculpture, Frankfurt-am-Main / Bern / New York, 1985 (Europä̈sche Hochschulschriften, Reihe XXXVII, Archäologie, 11), p. 44. Cf.

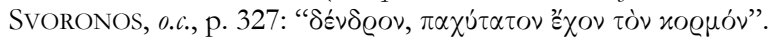

2 On the statuesque aspect of this Pan see Svoronos, o.c., p. 327, who describes the god as

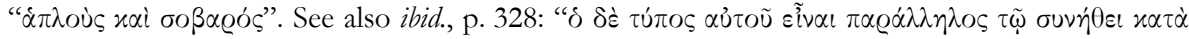

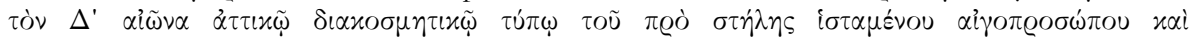

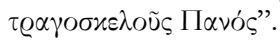

${ }^{3}$ Unlike caves, trees do not seem to play a part in Pan's iconography but appear in his representations simply as landscape motifs; J. BOARDMAN, s.v. "Pan", LIMC VIII (1997), n. 34, 68, 90, 113, 117, 130, 140, 175, 181, 184, 196, 197, 218, 222, 224, 245; cf. R.S. WaGman, "Two Inscribed Sculptural Representations of Pan from Epidauros", ZPE 93 (1992), p. 45-46, n. 3.

${ }^{4}$ Cave of the centaur Pholos: Corinthian skyphos, Paris, Louvre MNC 677 (M. LEvENTOPOULOU, s.v. "Kentauri et Kentaurides", LIMC VIII [1997], n. 252). Cave of the giant Alkyoneus: black-figured Attic hydria of the 'Leagros Group', London, B.M. B 314 (L. OLmos and L.J.

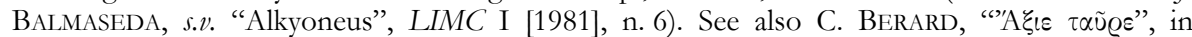
Mélanges d'bistoire ancienne et d'archéologie offerts à Paul Collart, Lausanne, 1976 (Cabiers d'Archéologie Romande de la Bibliothèque bistorique vaudoise, 5), p. 62-63.

5 Napoli, Mus. Naz. 6683 (S. WoOdFord and J. SpIER, s.v. "Kerberos", LIMC VI [1992], n. 56). See also a sarcophagus in Florence, Mus. Uffizi 110 (ibid., 30, cat. 75, pl. 15), dating to the same period. On the cave in Greek art, in addition to the earlier works by M. JOBST, Die Höle im griechischen Theater des 5. und 4. Jarbunderts v. Chr. Eine Untersuchung zur Inszenierung klassischer Dramen, Wien, 1970 (Österreichische Akademie der Wissenschaften, Philosophisch-Historische Klasse-Sitzungsberichte, 268, 2. Abhandlung), especially p. 83 ff., and C.M. EDwARDS, Greek Votive Reliefs to Pan and the Nymphs, Diss. New York University, 1985, especially p. 59-63, see now the study by G. SIEBERT, "Imaginaire de la grotte dans la Grèce archaïque et classique", in G. SIEBERT (ed.), Nature et paysage dans la pensée et l'environnement des civilisations antiques: Actes du Colloque de Strasbourg, 11-12 juin 1992, Paris, 1996 (Travaux du Centre de recherche sur le Proche-Orient et la Grèce antiques, 14), p. 47-57. 
Rarely do we hear of a sacred cave without a tree or trees standing nearby. ${ }^{6}$ So close is this connection between tree and cave that even when they occur separately, one may evoke the image of the other in the viewer's mind. Pausanias describes a tree in Messenia, hollow inside, from which flowed a fresh water spring. To convey an idea of what the plant looked like, the geographer compares it with the natural object that he is most reminded of-a cave: ${ }^{7}$

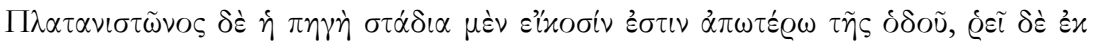

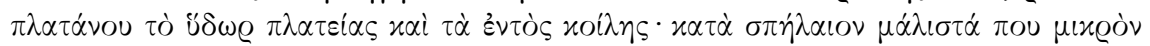

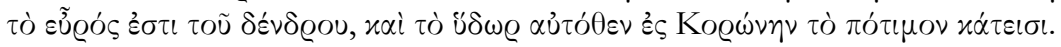

Twenty stades off the road is the fountain of Plataniston, the water of which flows out of a broad plane tree, which is hollow inside. The breadth of the tree gives the impression of a small cave; from it the drinking water flows to Corone.

Tree and cave overlap also in a votive epigram from Thasos recording the dedication of a small hypaethral sanctuary for Dionysus (this text, still unpublished, is only available in French translation). Here a vine arbor encircling the sacred space is called "a beautiful grotto, evergreen": 8

Pour toi, un temple à ciel ouvert, enfermant un autel, et son berceau de pampres, ô prince des Ménades, un bel antre toujours vert, voici, Dionysos Baccheus, ce qu'a fondé Timocleidès, fils de Diphilos.

This blurring of boundaries between the vegetal and the mineral world is especially evident in vase-painting, where the tendency to compress and

${ }^{6}$ Trees growing in the vicinity of caves, individually or in small stands, appear in Greek literature from Homer onwards, see e.g. Od. XIII, 102-103 (single tree: olive) and IX, 182-183 (tree cluster: laurels). For some real life examples, see the cave of Phylae on Mt. Parnes (single tree: plane. J. LarSON, Greek Nymphs. Myth, Cult, Lore, New York, 2001, p. 48, fig. I.3) and the cave of Alogopati near Pharsalus (tree cluster: wild figs. D. LEVI, "L'antro delle Ninfe e di Pan a Farsalo in Tessaglia", ASAA 6 [1923], p. 30). In the natural world the occurrence of trees near caves is linked of course to the presence of running water, a recurring feature of Nymph and Pan shrines (the aforementioned site of Alogopati, where an ancient stream has excavated its course into the floor of the cave, is an appropriate example; see LEVI, l.c., p. 31-32, fig. 6. As shown by the passage from $O d$. XIII cited above, spring water is also a traditional element of literary cavescapes).

7 Paus., IV, 34, 4.

8 Guide de Thasos, Athens, 1967 (École française d'Athènes. Sites et monuments, 3, 1), p. 172. On Thasos another similar Dionysiac arbor, formed by the curving branches of a vine, appears in the pediment of a small rupestrial chapel to Pan, ibid., p. 57-58 (left corner: for a description and a line-drawing of the relief, no longer discernible on the rock, see P. Devambez, "La 'Grotte de Pan' à Thasos", in Mélanges Collart [above, note 4], p. 120, fig. 3). For further examples of this type of 'cave' in Dionysiac iconography, where "le dôme est formé uniquement de feuillages, vigne ou lierre", see the examples cited by BÉRARD, l.c. (n. 4), p. 62, n. 6. On the Bacchic cave in general, in addition to the classic study by P. Boyancé, "L'antre dans les mystères de Dionysos", RendPontAcc 33 (1961), p. 107-127, see the overview by H. Lavagne, Operosa Antra. Recherches sur la grotte à Rome de Sylla à Hadrien, Rome, 1988 (BEFAR, 272), p. 47-55, 87-126-especially 87-89 on the floral and vegetal element. 
conflate is accentuated by the restrictions of the medium. ${ }^{9}$ A striking example is that of a calyx-krater at the Staatliche Museum of Berlin, n. 3237.10 In this vase the painter has compiled different scenes from the myth of Antiope-the capture of Lycus at the hands of Antiope's sons and the agony of Dirce dragged by the bull-arranging them against the background of a cave. The cave, presumably the one used by Antiope to conceal Amphion and Zetus, is shown as an arched opening seen from the front. Here we find again the amalgamation of plant and rock observed in Athens NM 1382, except in a reversed order: instead of a tree turned into lifeless stone, we see the rocky mass of the cave transformed into a live plant that folds over the central scene with a lithe, sinuous movement. ${ }^{11}$ More similar to our relief, for the use of profile view and the arrangement of compositional elements, is a lekythos at the Metropolitan Museum in New York, 56.171.58, showing Philoctetes in the act of inspecting his wound. ${ }^{12}$ In accordance with iconographical convention, the hero is represented seated on a rock, the wounded leg resting on a tree stump. To the left of the composition another tree rises behind the figure, curving over it with one of its branches. Although this plant retains all the vegetal suppleness that is absent in the tree of the Athenian relief, there can be no doubt that its semiarched form is intended to suggest a profiled cave. Just as the boulder where Philoctetes sits is symbolic of the island of Lemnos, the tree that folds over the hero in a broad half-arch is an allusion to the cave where he spent his exile.

One could argue that at the heart of this iconographical peculiarity is neither a tree nor a cave, but the arched shape which is common to both. The curved shape came to be considered such a defining feature of cave shrines that, when it did not occur naturally, it was sometimes supplied by architectural means; such is the case, for example, of the celebrated school of Aristotle near Mieza, or the recently excavated site of Krounia in Southeast Thessaly, both showing artificially rounded cave openings. ${ }^{13}$

\footnotetext{
${ }^{9}$ For a summary of the problems associated with the depiction of caves in vase-painting see SIEBERT, l.c. (n. 5), p. 155.

${ }^{10}$ SiEBeRT, l.c. (n. 5), pl. III: 3 and fig. $2: 5$.

11 The literary analog that leaps to mind are the laurels arching over the Cyclops' cave in $O d$. IX, 182-183 (note 6 above). SIEBERT effectively describes the phenomenon in the following terms: "les éléments constitutifs de la grotte, le rocher et la végétation, sont liés au point que la seconde peut se substituer au premier", l.c. (n. 5), p. 154.

12 SIEBERT, l.c. (n. 5), pl. I: 2; see comments at p. 154: "un arbre dessine comme une voûte protectrice au-dessus de Philoctète. On voit ici le passage de la grotte au berceau de verdure."

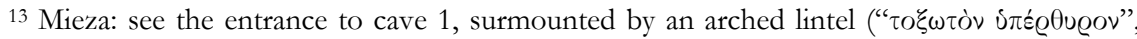
PAAH [1965], p. 40, fig. 4 and pl. 46; cf. EAAH [1965], p. 23-24, figs. 21, 23; BCH 90 [1966],

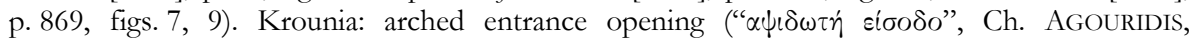

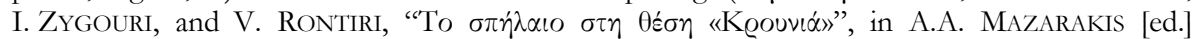

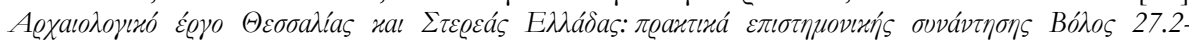

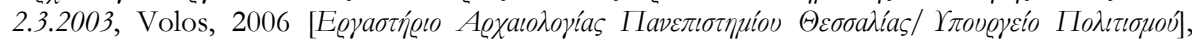
p. 249 and figs. 2, 6; see also p. 250).
} 
Returning to our relief. The evidence considered above supports the initial suggestion that the lack of movement in the landscape of NM 1382 stems from the overlapping of two different pictorial motifs, the tree and the cave. A tendency-sometimes subtle, sometimes explicit-to blur the semantic boundaries that separate these two landscape elements can be traced across a wide range of literary and artistic examples, showing that tree and cave lend themselves to a form of metonymic exchange. This could be explained by the physical contiguity that tree and cave often share in the natural world (especially in the semi-controlled environment of Nymph and Pan shrines, where caves are frequently planted with trees) as well by some archetypic forms common to both, such as the arch and semiarch. Awareness of this pattern could prove useful in interpreting Greek landscape iconography. If nothing else, it also serves as a reminder that visual materials can be used as pliably as verbal ones for the communication of subtle meanings. ${ }^{14}$

Department of Classics and Center for Greek Studies

Robert S. WAGMAN University of Florida, GAINESVILLE, U.S.

E-mail:rsw@ufl.edu

\footnotetext{
14 Beyond the cave-tree conflation examined in this study, caves lend themselves to other forms of visual play. See e.g. the subtle blending of rock and human limb in a lekythos from Athens showing the transformation of Odysseus' companions in Circe's cave (National Museum $9685=$ SIEBERT, l.c. [n. 5], pl. II: 3) or rock and snake contours in another lekythos from Paris depicting Apollo's arrival at Delphi (Cabinet des Médailles, inv. $306=$ SIEBERT, l.c. [n. 5], pl. IV: 2).
} 